\title{
Archaeological Survey and Geoarchaeological Investigations at 41BX1271, Walker Ranch Park, Bexar County, Texas
}

Jason D. Weston

Follow this and additional works at: https://scholarworks.sfasu.edu/ita

Part of the American Material Culture Commons, Archaeological Anthropology Commons, Environmental Studies Commons, Other American Studies Commons, Other Arts and Humanities Commons, Other History of Art, Architecture, and Archaeology Commons, and the United States History Commons

Tell us how this article helped you.

This Article is brought to you for free and open access by the Center for Regional Heritage Research at SFA ScholarWorks. It has been accepted for inclusion in Index of Texas Archaeology: Open Access Gray Literature from the Lone Star State by an authorized editor of SFA ScholarWorks. For more information, please contact cdsscholarworks@sfasu.edu. 


\section{Archaeological Survey and Geoarchaeological Investigations at 41BX1271, Walker Ranch Park, Bexar County, Texas}

\section{Licensing Statement}

This is a work produced for the Texas Department of Transportation (TxDOT) by the report producer. TxDOT and the report producer jointly own all rights, title, and interest in and to all intellectual property developed under TXDOT's contract with the report producer. The report may be cited and brief passages from this publication may be reproduced without permission provided that credit is given to both TXDOT and the report producer. Permission to reprint an entire chapter, section, figures or tables must be obtained in advance from either the Supervisor of the Archeological Studies Branch, Environmental Affairs Division, Texas Department of Transportation, 125 East 11th Street, Austin, Texas, 78701 or from the report producer. 


\title{
Archaeological Survey and Geoarchaeological Investigations at 41BX1271, Walker Ranch Park, Bexar County, Texas
}

\author{
by \\ Jason D. Weston
}

with a contribution by

Russell D. Greaves

Texas Antiquities Permit No. 3023

Center for Archaeological Research The University of Texas at San Antonio Archaeological Survey Report, No. 337 2003

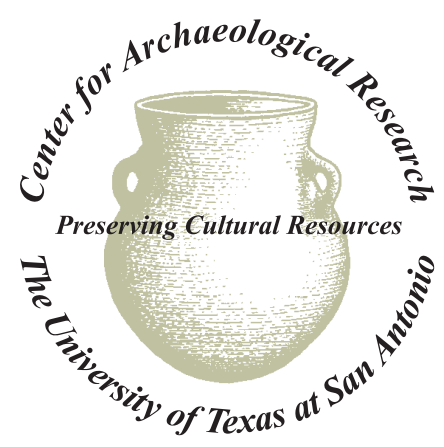




\title{
Archaeological Survey and Geoarchaeological Investigations at 41BX1271, Walker Ranch Park, Bexar County, Texas
}

\author{
by \\ Jason D. Weston \\ with a contribution by \\ Russell D. Greaves
}

Principal Investigator

Raymond P. Mauldin

Texas Antiquities Permit No. 3023

(C) copyright 2003

Center for Archaeological Research

The University of Texas at San Antonio

Archaeological Survey Report, No. 337 
The following information is provided in accordance with the General Rules of Practice and Procedure, Chapter 26.24 (Investigative Reports), Texas Antiquities Committee:

1. Type of investigation: Intensive Survey

2. Project name: Walker Ranch Park Survey (41BX1271)

3. County: Bexar

4. Principal investigator: Raymond P. Mauldin

5. Name and location of sponsoring agency: City of San Antonio Parks and Recreation Department

6. Texas Antiquities Permit No.: 3023

7. Published by the Center for Archaeological Research, The University of Texas at San Antonio, 6900 N. Loop 1604 W., San Antonio, Texas 78249-0658, 2003

A list of publications offered by the Center for Archaeological Research is available. Call (210) 458-4378; write to the Center for Archaeological Research, The University of Texas at San Antonio, 6900 N. Loop 1604 W., San Antonio, Texas 78249-0658; e-mail to car@lonestar.utsa.edu; or visit CAR's web site at http://car.utsa.edu. 


\section{Abstract:}

In January of 2003, a crew from the Center for Archaeological Research at The University of Texas at San Antonio conducted an archaeological survey and geoarchaeological investigations at site 41BX1271 in Walker Ranch Park for the San Antonio Parks and Recreation Department. This work was done in response to the planned installation of security lights around the existing park trail and a drinking fountain along the southwest portion of the trail system. The archaeological investigations were carried out under Texas Antiquities Permit No. 3023. Three separate field tasks were carried out in order to perform the required assessment: 1) pedestrian survey of the planned installation area; 2) excavation of 41 shovel tests; and 3) excavation of two geoarchaeological test units. This report details the recovery of prehistoric artifacts as well as recent materials within the geological deposits of the park. Discussion of the park soils and geology in relation to artifacts and human occupation is also provided.

The archaeological investigations and artifacts recovered indicate a low density of cultural materials and low research potential for the area impacted by the planned modifications. While the lighting and fountain installations will impact the sparse cultural remains, these resources have low interpretive and scientific value and would not contribute significant new knowledge to existing information on Walker Ranch or the prehistory of the region. 


\section{Table of Contents:}

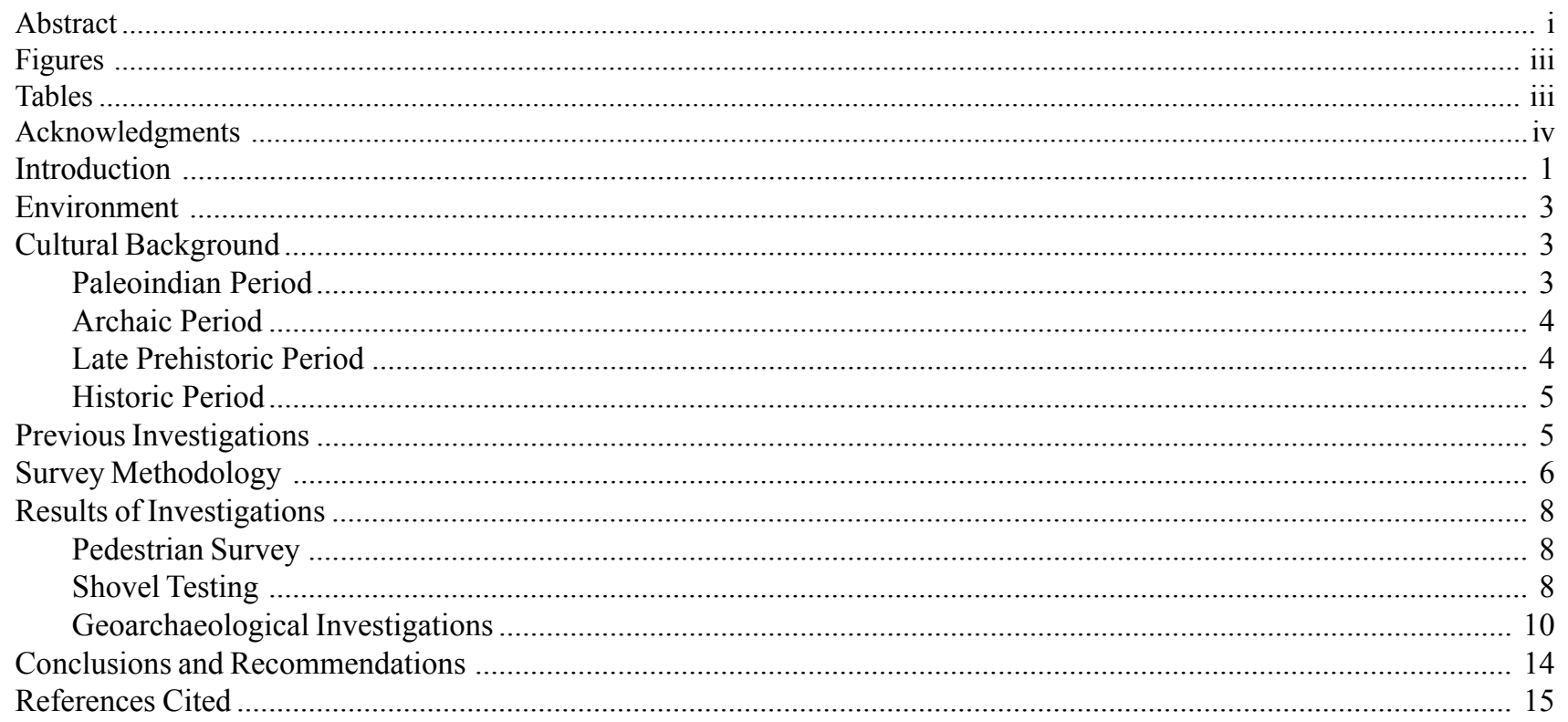




\section{Figures:}

Figure 1. Location of Walker Ranch Park project area...................................................................................... 1

Figure 2. Proposed locations of light poles and electrical and waterline routes within the park. .................................. 2

Figure 3. Distribution of shovel tests excavated within the project area in 1997 and during the current survey................. 7

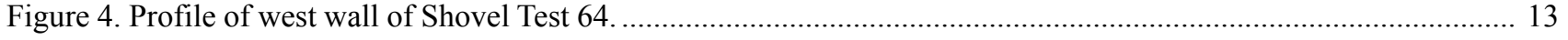

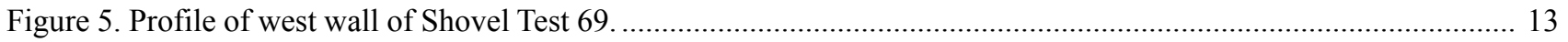

\section{Tables:}

Table 1. Numbers and Categories of Artifacts Recovered in Shovel Tests ................................................................... 9

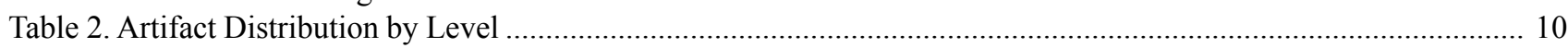

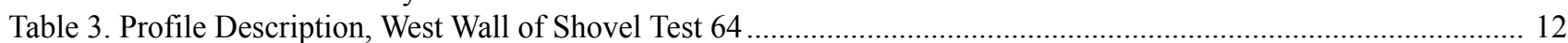

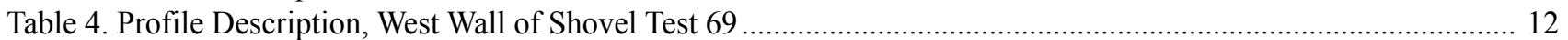




\section{Acknowledgments:}

The author would like to thank Steve Uncapher and all San Antonio Parks and Recreation Department staff and employees involved in this project for their assistance and cooperation. The concern and attention they have given to possible disturbances to cultural resources in Walker Ranch Park is deeply appreciated. Also a thanks goes out to CAR crew members Jennifer Neel-Hartman, Bruce Moses and Stacy Wagner for their work in the field. Bruce and Stacy mapped the park, Jennifer processed the artifacts in the lab, and Bruce and Rick Young drafted the figures in this report. The geoarchaeological work done by CAR personnel Dr. Russell Greaves and Leonard Kemp. Thanks also to Dr. Raymond Mauldin, Principal Investigator for this project, for his assistance in all phases of the project and Dr. Harry Shafer who read and polished sections of this report. Johanna Hunziker edited and formatted the final report. 


\section{Introduction}

In January 2003, a crew from the Center for Archaeological Research (CAR) at The University of Texas at San Antonio conducted a pedestrian survey, shovel testing, and geomorphic assessment of the Walker Ranch Park Trail Improvements Project for the City of San Antonio Parks and Recreation Department. Walker Ranch Park is located adjacent to and on the west side of West Avenue between the upper reaches of Salado and Panther Springs creeks, just upstream from the confluence of the two creeks (Figure 1).

The planned trail improvements project is to include lighting improvements and the installation of a water fountain. The lighting improvements consist of the installation of 18 concrete light poles next to the existing park trail which makes a half-mile-long, meandering loop between the two creeks (Figure 2). The area of potential effect from the construction activities associated with the lighting improvements will include 26-inch diameter holes dug to a depth of 6 feet to house the 18 concrete light poles and an approximately 3,450-foot-long, 6-inch-wide, and 24-inchdeep trench to house the electrical wires within a plastic conduit connecting the poles. The area of potential effect from the installation of the waterline consists of a 6-inchwide trench dug to a depth of only 8 inches below surface and running 875 feet along the southern portion of the trail system to the vicinity of West Avenue where it will join the existing water main (Figure 2). The fountain is to be installed near the southwestern end of the trail loop and the overflow for this water fountain will be drained in a pipe installed in a 50-foot-long, 16-inch-deep trench leading to the active channel of Salado Creek (Figure 2).

Due to the fact that the entire park area is part of site 41BX1271, and previous archaeological surveys have identified archaeological deposits in the vicinity of the trail (see Previous Investigations section), it was necessary to

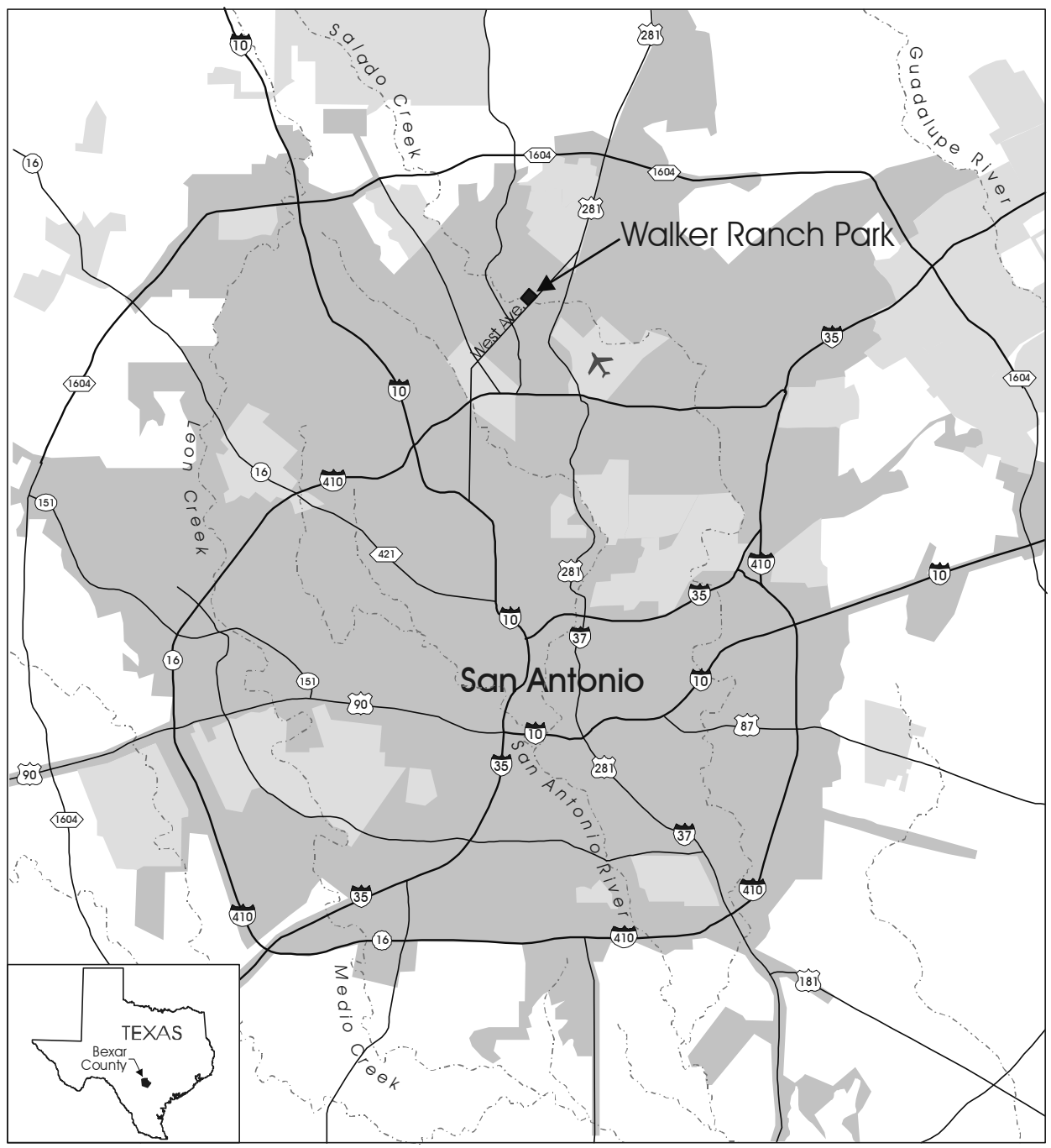

Figure 1. Location of Walker Ranch Park project area. 


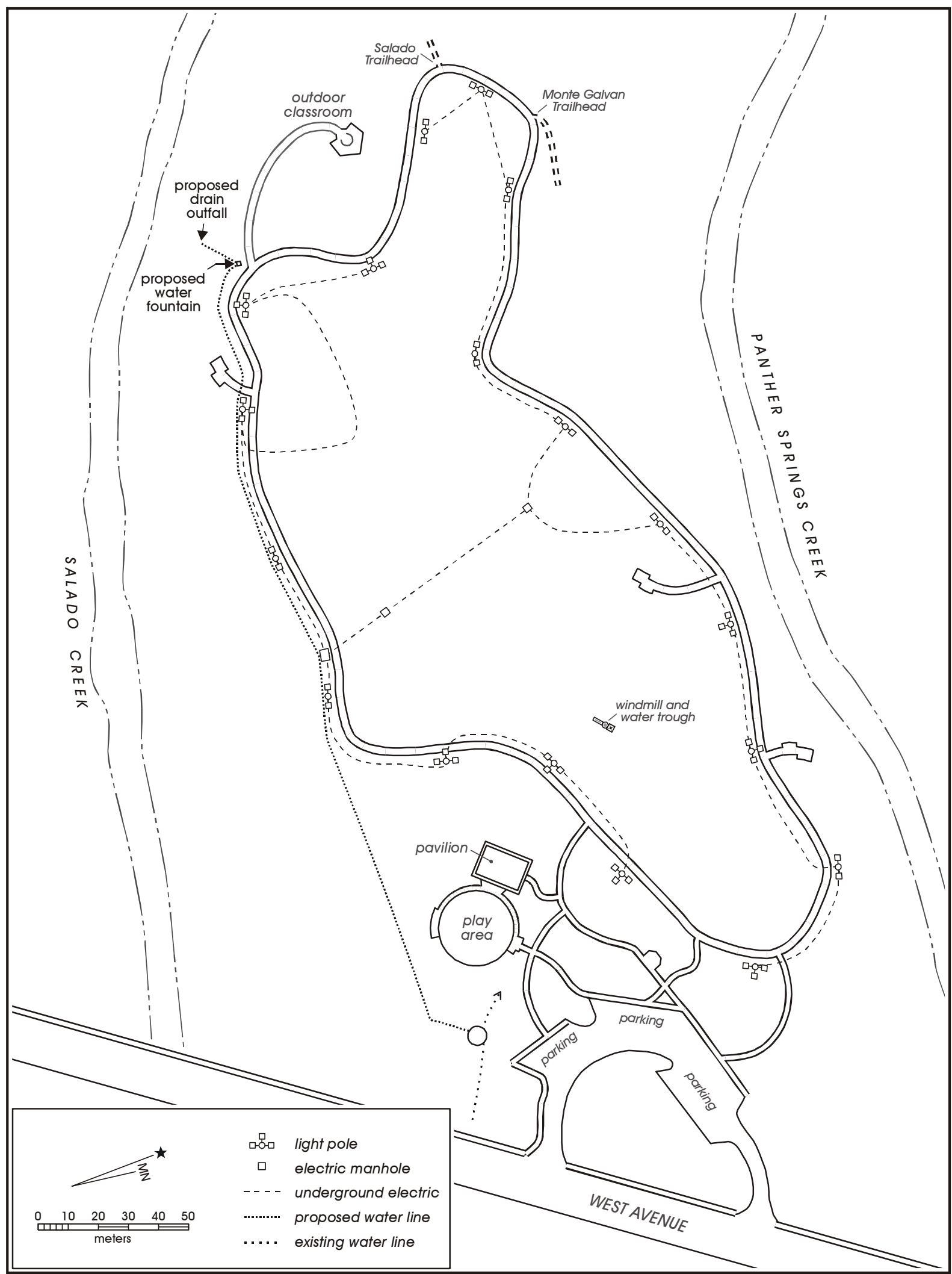

Figure 2. Proposed locations of light poles and electrical and waterline routes within the park. 
conduct archaeological investigations to identify whether the construction-related impacts will disturb any intact or significant cultural deposits. These investigations were conducted under Texas Antiquities Permit No. 3023.

\section{Environment}

The project area is located along the southern border of the Edwards Plateau, in the Balcones Canyonlands natural subregion of Texas (LBJ School of Public Affairs 1978). The landscape is dissected by numerous high-gradient streams in steep-sided canyons that flow south and southeast to the Gulf of Mexico (Riskind and Diamond 1988:1). These streams would have provided ideal locations for prehistoric valley-bottom seasonal camps.

Bexar County has a subtropical climate with warm winters and hot summers. The average winter temperature is $58^{\circ} \mathrm{F}$ $\left(14^{\circ} \mathrm{C}\right)$ and the average summer temperature is $80^{\circ} \mathrm{F}\left(27^{\circ} \mathrm{C}\right.$; Bomar 1995). The growing season averages 245 days a year in the northern half of the county and 275 days a year in the southern half of the county. The prevailing winds are light ( 8 knots) and predominately blow from the southeast. The average annual precipitation is 31 inches $(787 \mathrm{~mm})$, with rainfall evenly distributed throughout the year (Taylor et al. 1991:118). Atlantic hurricanes occasionally affect the county, causing high winds and sporadic, heavy rainfall.

The immediate project area is located within the Upper Salado Creek watershed (Katz 1987; Potter et al. 1995). The soils are part of the Tarrant-Brackett association (Taylor et al. 1991) and consist of the Lewisville Series silty clays. These soils are common on terraces above the floodplains of larger creeks and rivers. The solum (upper portions of a soil profile where soil formational processes are still active) ranges from 20-66 inches $(50-150 \mathrm{~cm})$ in depth (Taylor et al. 1991:113) and, as such, has a strong potential to contain buried deposits. Specific soils information is discussed in the Geoarchaeological Investigations section of this report.

\section{Cultural Background}

The culture history and cultural chronology of the region, specifically western and northern Bexar County, is continuous for the past 11,500 years. On a regional scale, archaeologists have divided this chronology into periods and intervals in order to better isolate blocks of time for study and interpretation (Collins 1995). The broad periods are roughly defined on the basis of lifeways and hunting and gathering technologies and are identified by general similarities in artifact assemblages. Four broad periods have been defined: Paleoindian, Archaic, Late Prehistoric, and
Historic. Intervals within each of these time units are defined by diagnostic artifacts and artifact assemblages used during shorter increments of time.

Numerous archaeological investigations of prehistoric sites have been conducted in Bexar County, and have provided a good understanding of the local archaeology. (Black and McGraw 1985; Black et al. 1998; Collins 1995; Collins et al. 1998; Katz 1987; Lukowski 1988; Potter et al. 1995; Stothert 1989, to name but a few). On a regional scale, recent investigations have resulted in refined chronological models for the Canyonlands, which include northern Bexar County and the project area (Henderson 2001; Johnson 1991, 1995; Johnson and Goode 1994; Kibler and Scott 2000; Mahoney et al. 2003; Nickels et al. 2001).

The most common indicators of prehistoric sites in the Canyonlands are artifacts produced by chipping stone (flint or chert) in the manufacture of stone tools and stone altered by other cultural means. Stone artifacts are durable, whereas more perishable items, such as those made of hide, bone, or fiber, are much less likely to be preserved, if they are preserved at all. Therefore, archaeologists rely on stone or lithic artifacts to guide them to archaeological sites in the Canyonlands area. These lithic artifacts mainly fall into two classes: chipped stone and fire-cracked rock (FCR). Chipped stone includes artifacts made by chipping a mass into a tool form and the flake residue (debitage) created during this process. Archaeologists can tell by looking at these tools and flakes how they were made and how they were used. Fire-cracked rock was produced when limestone rocks were placed in pits in which fires were built to radiate the heat for earth oven baking. The heating alters the color of the rocks and causes them to fracture. Through time, the hearth features become disturbed by human and natural agencies and the rocks get displaced. When archaeologists find flakes and fire-cracked rock, these are important clues to the presence of an archaeological site.

\section{Paleoindian Period}

The earliest known cultural period, the Paleoindian, dates to between 9500-7000 B.C. (11,500-9000 BP [BP; before 1095]), and represents the time at the end of the last Ice Age when people first migrated into the New World and began to settle the continent. These hunter-gatherers initially hunted now-extinct megafauna such as mammoth and ice age bison, but through time, smaller animals dominated the subsistence economy. Diagnostic artifacts of the early part of this period are the fluted Clovis and Folsom points. Non-fluted points such as Plainview, Golondrina, and St. Mary's Hall characterize the later part of the Paleoindian period after the extirpation of the ice-age animals and when modern 
species were hunted. Early Paleoindian presence in Central Texas has been amply documented at the Gault Site (41BL323), site 41BX52 in northern Bexar County, and Kincaid Shelter in Uvalde County (Collins 1999). Late Paleoindian cultural remains have been documented in Bexar County at St. Mary's Hall (Hester 1990), Panther Springs Creek Site on the former Walker Ranch (Black and McGraw 1985:Figure 22), and in the Olmos basin (Stothert 1989).

\section{Archaic Period}

The Archaic period, dating from 7000 B.C. to A.D. 800 (9000-1200 BP), marks a long time span of hunting and gathering as the main lifestyle (Black and McGraw 1985). A spear tipped with large projectile points and thrust with a throwing stick (atlatl) was the principal hunting weapon for the period. The Archaic period is divided into three subperiods based on changes in patterns perceived in the archaeological record.

\section{Early Archaic (7000 to 4000 B.C.)}

Human populations in the Early Archaic were highly mobile (nomadic) groups sparsely scattered across the landscape. Diagnostic artifacts include projectile point forms and types such as Angostura, early split-stem (Uvalde and Gower), Bandy, and Martindale. Other tools include triangular adze blades (Clear Fork tools), elongated adzes (Guadalupe tools), and notched pebbles (Waco sinkers). Local sites with Early Archaic components include Richard Beene (Thoms et al. 1996), Panther Springs Creek Site (Black and McGraw 1985), and 41BX1 in the Olmos basin (Lukowski 1988; Stothert 1989). One of the important characteristics of Early Archaic sites is the first occurrence of burned rock features and the use of limestone in earth oven cooking, sometimes resulting in dense clusters of burned rocks or "proto burned rock middens" (Collins et al. 1998). Deer and smaller game such as rabbits were the major sources of meat.

\section{Middle Archaic (4000 to 2000 B.C.)}

Middle Archaic artifact assemblages show a continuation of the broad hunting and gathering patterns established in the preceding period. Site components of this period occur throughout the Salado Creek and upper San Antonio River watersheds (Black and McGraw 1985; Lukowski 1988; Stothert 1989). Point styles change and the adzes and sinkers are no longer produced, suggesting subtle shifts in regional ecology and lifeway changes. Diagnostic artifacts include projectile point types Bell, Early Triangular, and Nolan. The use of limestone in earth oven baking increased due to more intensive use of plant resources. Burned rock created by this process increase in abundance in locations in which earth ovens were constructed. Archaeological visibility of these activity areas includes scatters of burned rock, intact hearth features, and intentional mounded concentrations of burned rock called "burned rock middens." Deer and bison were the larger animal species exploited.

\section{Late Archaic (2000 B.C. to A.D. 800)}

The Late Archaic period represents a further development of Middle Archaic patterns and probably the first archaeological indication of established group territories. The use of local plant foods either intensified, or the populations were increasing. The results were a greater frequency of burned rock middens and earth oven cooking. Deer and bison continue as the larger game species exploited. Late Archaic site components occur throughout the Salado Creek and San Antonio River watersheds. Diagnostic artifacts for the period include projectile point types Pedernales, Montell, Castroville, Marshall, Marcos, and Ensor, and knife forms such as butted knives, corner tang, and base tang knives (Collins et al. 1998; Stothert 1989; Turner and Hester 1999:243).

\section{Late Prehistoric Period}

The Late Prehistoric (A.D. 800 to 1700) is marked by a major technological change, the introduction of the bow and arrow. Archaeologists have divided the period into two intervals or phases, Austin and Toyah, based on differences in the archaeological assemblages. Evidence for the change is seen in the replacement of large projectile points by small, delicately shaped arrow points. Late Prehistoric components commonly occur along the Salado Creek and upper San Antonio River drainages (Black and McGraw 1985; Stothert 1989).

The first part of the Late Prehistoric shows no significant change in subsistence from the Late Archaic period, as extensive use of earth ovens continued along with the formation of burned rock middens. Deer was the most important meat source. Diagnostic arrow point types for the Austin interval include corner-notched forms Scallorn, Edwards, and Sabinal. The most significant change occurs in the latter part of the period with the Toyah interval when bison reappear across Central Texas and the Canyonlands after an absence during the early part of the Late Prehistoric. Deer continued to be exploited, but the quest for bison may have changed traditional territorial ranges and the human landscape. Perdiz replaced the corner-notched forms as the major arrow point style, and pottery was produced in the region for the first time. The overall artifact assemblage reflects an economy that incorporated hunting and hide processing. Many of the groups known through archaeology in this period can be seen as having a cultural relation to groups known historically. 


\section{Historic Period}

The historic period is essentially defined by contact with European cultures and/or the American culture (United States). Although Cabeza de Vaca passed through parts of southern Texas in the early 1500s (Krieger 2002), several early Spanish entradas crossed the project area in the late seventeenth and early eighteenth centuries. In 1691, Don Domingo Terán de los Rios and Father Damian Massanet's party camped around the springs that form the San Antonio River. These were probably San Pedro Springs. Terán gave the stream the name San Antonio de Padua because the thirteenth of June was the saint's day. Terán's party also encountered a large encampment of Payaya Indians, a local group linguistically affiliated with the Coahuiltecan speakers of southern Texas and northern Mexico (Campbell 1975).

Spanish incursions into the region were followed by the establishment of the first of several missions along the San Antonio River. A contemporary of the late seventeenth century, Juan Bautista Chapa provides one of the earliest documentations of this presence by mentioning the "...Mission of San Antonio, forty leagues from Monterrey..." in his Historia del Nuevo Reino de León (Chapa 1997:91).

Mission San Antonio de Valero, now known as the Alamo, was among the first missions established along the San Antonio River, in 1718 (it was moved to its present location in 1724). Other missions include San José y San Miguel de Aguayo (1720), Nuestra Señora de la Purisima Concepción de Acuña (1731), San Francisco de la Espada (1731), and San Juan Capistrano (1731).

From the 1600s through the 1800s, the Historic period (both Colonial and post-Colonial) in the San Antonio-Bexar County area was characterized by a ranching economy. In the early part of the nineteenth century native peoples, particularly Comanche, raided settlements to hold back the immigrant tide and foreign government control gave way to the domestic governments of Mexico, then Texas, and finally United States. Throughout all of these changes, ranching remained the dominant way of life in the Bexar County area from the late seventeenth century into the twentieth century.

As the name would suggest, the current project area was a part of the Walker Ranch. Although there is rumor of a Spanish occupation, the Walker Ranch was first recorded as Survey \#79 in 1838 owned by Sterling N. Dobie. After having been owned by several proprietors, in 1873 the ranch was purchased by the Ganahl-Walker family (Fox 1979:3). By the late nineteenth century, the Walkers had added more land to the ranch and maintained it until 1973 when major sell-off to developers began for the building of subdivisions (Fox 1979).

\section{Previous Investigations}

As of December 2002, nearly 1,500 archaeological sites had been recorded in Bexar County. The majority of these sites are located along the Medina and San Antonio rivers and their tributaries such as Salado Creek. For this project, it is those sites on the upper Salado Creek and its tributary Panther Springs Creek in the vicinity of the park that are of concern. In this vicinity alone there are around 40 recorded sites.

The first archaeological investigations conducted within the limits of the former Walker Ranch occurred in 1973-1974 under the direction of the Texas Historical Commission (THC). This work was responsible for identifying 43 sites (Potter and Black 1995) and led to the establishment of the Walker Ranch National Historic District (Fox 1979). The next archaeological work done in the Walker Ranch area was by crews from CAR in 1974. This work was conducted to survey locations for proposed floodwater retarding structures on the Salado Creek Watershed. Retarding Structure \#7 is the closest to the current project area; it is located along Panther Springs Creek less than a mile above Walker Ranch Park (41BX1271). Nine archaeological sites (41BX180, 184, 191, 192, 197, 217, 222, 223, and 228) found by the 1973 THC survey were re-evaluated in the vicinity of Structure \#7. Site 41BX228 was one of the most impressive of these nine sites along Panther Springs Creek. At the time of its discovery, the site consisted of several burned rock middens and a considerable deposit of lithic artifacts. It was recommended for further testing (Hester et al. 1974). In 1977, survey crews from CAR identified and investigated several rockshelter sites farther up Panther Springs Creek. The investigations at these sites produced debitage, biface fragments, and untyped stemmed dart points (McGraw and Valdez 1978).

CAR investigated the historic ruins at 41BX180 in 1979. The main features at this site are the remaining walls of three stone structures and three cisterns that date to the late nineteenth century (Fox 1979). CAR crews assessed 41BX197 through survey and limited testing. The site was found to contain lithic debitage, non-diagnostic bifacial tools, and historic debris from the nearby Walker Ranch Complex (Potter 1980). Also in 1979, CAR began a new phase of work at 41BX228, now called the Panther Springs Creek Site, consisting of full-scale excavations (mitigation). The multicomponent site contained burned rock middens, bifaces and lithic debitage, distally beveled bifaces called Guadalupe tools, 19 different types of dart points and four types of arrow points, bone and antler tools, and abundant faunal remains (Black and McGraw 
1985). The site occupation was found to span at least 5,000 years from the Early Archaic to the Late Prehistoric (Black and McGraw 1985).

Most of the more recent investigations along Salado Creek and its tributaries have also been conducted by CAR but have taken place upstream (to the north) or downstream (to the south) well away from the current project area (Brown et al. 1977; Burkett 1989; Burkett and Huebner 1989; Katz 1987; Miller 2001).

One of the more recent archaeological investigations in the vicinity of Walker Ranch Park was a survey by the Texas Department of Transportation (TxDOT) for the planned Wurzbach Parkway in 1991. Following this survey, from 1992 through 1994, the Texas Archeological Research Laboratory (TARL) evaluated five sites in the Walker Ranch National Historic District. The five sites include 41BX222, 223, 228, 949, and 996. The Walker family had problems with looters since the mid twentieth century and TARL crews found that the looting had not abated. The once impressive site of 41BX228 has been decimated by such destructive activities (Potter and Black 1995). 41BX996 was found to date back as far as 9,500 years and contained a large amount of debitage, rough bifaces, Guadalupe tools, chipped stone adzes, perforators, unifaces, La Jita dart points, modified flakes, and ground stone manos and metates (Black et al. 1998).

The first archaeological work actually conducted in Walker Ranch Park since its creation was in 1997 by CAR (Tomka 1998). That survey found a thin scatter of non-diagnostic prehistoric materials throughout the park and noted two concentrations of historic materials from the late nineteenth to early twentieth centuries (Tomka 1998). It is based on the results of the 1997 survey, that much of the park was designated archaeological site 41BX1271.

During the 1997 survey, shovel tests were placed in the route of the planned park trail and the planned locations of a parking lot, play area, and pavilion. The shovel testing indicated that the entire southeastern portion of the park area to be heavily disturbed from former parking lot construction and the construction and demolition of residential properties in this area (see Tomka 1998:11, Figure 1). The eastern half of the waterline is to be installed in this heavily disturbed portion of the project area while the western half will run along the existing park trail (Figure 2). The proposed park improvements service the park trail constructed following the 1997 CAR work.

The latest archaeological work conducted at Walker Ranch Park occurred in January 2000 and consisted of the monitoring of construction associated with an outdoor classroom and walkway along the western edge of the trail (Figure 2; Meissner 2000). The pedestrian survey of the area of potential effect indicated a sparse surface scatter of lithics, historic and recent materials, and exposed bedrock along the western margin adjacent to Salado Creek.

\section{Survey Methodology}

As indicated earlier, the distribution and types of archaeological materials expected within the project area were reasonably well known prior to the inception of the project, based on previous archaeological work at Walker Ranch. Previous projects documented heavy subsurface disturbance in the east-central portion of Walker Ranch adjacent to West Avenue (Tomka 1998). In addition, the monitoring of the construction of the outdoor classroom on the north descending bank of Salado Creek also indicated that the bank has been heavily scoured and the thin (3-5 in) topsoil on the sloping bank is of colluvial origin (Meissner 2000). This was confirmed during the initial pedestrian survey of the project area conducted for the current survey (see Results of Investigations).

Based on this information, it was decided that shovel testing of the waterline trench in the south-central portion of the project area, between roughly Shovel Test (ST) 35 and ST 5 from the 1997 work (see Figure 3 and Tomka 1998) would not be necessary because of the documented disturbed nature of the deposits in this portion of the park. Similarly, because of the thin colluvial deposits present in the area of the fountain drain, no shovel testing would be needed there since any encountered deposits would be in secondary context. Given these decisions, the archaeological work conducted in association with the project focused on the area immediately adjacent to and along the existing trail.

The archaeological investigations consisted of a 100 percent pedestrian survey, shovel testing, and the hand-excavation of two geoarchaeological test units. A pedestrian survey of the light pole locations, the entire electric line route and the portion of the waterline route along the south-central portion of the trail between previously excavated STs 24 and 35 (see Figures 2 and 3 for approximate locations and route), was conducted prior to initiation of shovel testing. Cultural materials seen on the surface during the pedestrian survey were noted and described but not collected.

Shovel testing began at the planned location of each light pole. When evidence of cultural activity was encountered in a shovel test, additional shovel tests were excavated in the immediate vicinity along the path of the electric line route to define the extent of the distribution. Aside from 


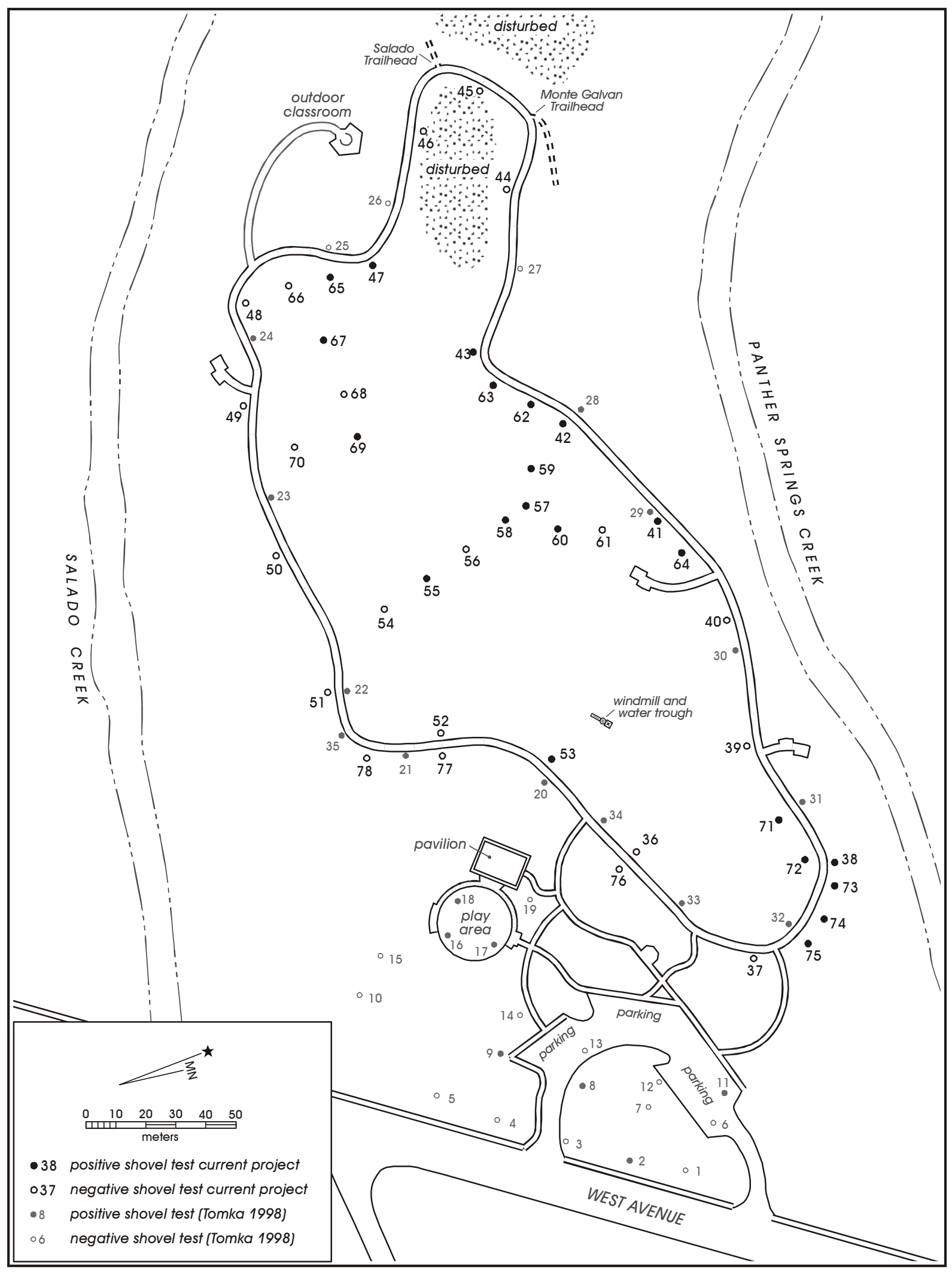

Figure 3. Distribution of shovel tests dug within the project area in 1997 and during the current survey. 
light pole locations, several shovel tests were placed along the electric line route where it deviated from the trailside and crossed the center of the park (Figure 3). The shovel tests excavated along the south-central portion of the trail served to investigate the deposits that would be impacted by both planned water and electric lines.

Shovel tests were $30-\mathrm{cm}$ diameter units excavated to a depth of $60-\mathrm{cm}$ below surface $(\mathrm{cmbs})$ or until the sterile substrate was encountered. The shovel tests were excavated in 10$\mathrm{cm}$ thick levels. All matrix from these excavations was screened through $1 / 4$-inch mesh, all artifacts were collected, and observations related to soil characteristics and artifact recovery were recorded on standardized forms. All shovel test locations were recorded using a Trimble Geo Explorer II Global Positioning System (GPS) unit. In addition, the entire trail and all shovel test locations and park landmarks (e.g., windmill, outdoor classroom, parking lot) were mapped using a Total Data Station (Sokkia Set 6E Total Station and SDR33 Data Collector). The result of this geographical survey has generated a extremely accurate maps of the park (Figures 2 and 3).

The numbering sequence for the shovel tests dug during this survey continues where the 1997 CAR survey left off (nos. 1 through 35; Tomka 1998). Figure 3 shows the shovel tests excavated in 1997 and 2003 that fall within the trail. While the actual locations of many of the 35 previously excavated shovel tests are in the current trail, in Figure 3 they are depicted just off the trail for clarity and legibility.

Because the depositional context of the materials observed in the 1997 investigations at Walker Ranch was not well understood, it was hoped that limited geomorphic work during this project could shed light on this issue. Therefore, two (ST 64 and ST 69) of the 43 shovel tests excavated during this project were expanded to $50-\mathrm{x}-50$ $\mathrm{cm}$ units to provide larger profile views for geoarchaeological examination and description. These two units were excavated in 10-cm levels, all soil was screened through 1/4-inch mesh, and all cultural materials were collected. Profiling and description were performed after completion of each shovel test. Field soil observations included soil texture, consistence (wet only), presence and morphology of clay films, grain coatings, structure, abundance and size of roots, abundance and size of pores, $\mathrm{HCl}$ (hydrochloric acid) reaction, horizon boundaries, and Munsell colors (wet only). These attributes permit designation of the soil and sedimentary horizons in standard soil nomenclature (Soil Survey Staff 1993:117-135). The abundance and size of clasts also was recorded.

\section{Results of Investigations}

\section{Pedestrian Survey}

The project archaeologist conducted the pedestrian survey of the entire project area following the January 16, 2003 on-site meeting with staff from the San Antonio Parks and Recreation Department. At this time, the project archaeologist accompanied Mr. Steve Uncapher and Mr. Richard Caudell of the Parks Department during the walk-through for the final layout of the electric line route and light pole locations. Both the electric and waterline routes were surveyed. Surface visibility along the planned trench route ranged from 0-60 percent. Chipped stone artifacts and debris noted during the pedestrian survey consisted of two cores and three unmodified flakes. One flake was found near the eventual location of ST 43 (Figure 3). The second flake was found near the eventual location of ST 57 , while the third flake was noted near the eventual location of ST 69 (Figure 3). The two cores were bifacially flaked multidirectional specimens. One was located on the bluff edge of Panther Springs Creek, across the trail but in the vicinity of ST 43. The second was on the left descending bank of Salado Creek, near the outdoor classroom.

\section{Shovel Testing}

A total of 43 shovel tests was excavated during this project, including the two (STs 64 and 69) that were expanded into 50-x-50-cm units. Of these, 20 shovel tests (nos. 36-53 and 76-77) were excavated at the locations of the 18 light poles. Shovel tests 36 and 52 were excavated at the original planned locations of light poles. The positions of these two poles were later changed and two new shovel tests (STs 76 and 77) were excavated at these new locations across the sidewalk (Figure 3). The remaining 23 shovel tests were excavated along the electric line route connecting the lighting poles. Five (12\%; STs $48-51$, and 78 ) of the 43 shovel tests excavated along the trail also fell within the planned waterline route along the south-central portion of the trail.

Of the 43 shovel tests, 24 (56\%) encountered bedrock and six $(14 \%)$ were excavated in previously disturbed construction fill. Twenty-two (51.2\%) of the shovel tests contained artifacts (see Figure 3 and Table 1). Of these 22 shovel tests, seven $(31.9 \%)$ recovered both historic and prehistoric cultural materials, three (13.6\%) produced only historic artifacts, $11(50 \%)$ yielded prehistoric artifacts only, and one ( $4.5 \%$ ) produced a single unidentifiable animal bone fragment. Table 1 provides a summary of the recovered cultural materials. 
Table 1. Numbers and Categories of Artifacts Recovered in Shovel Tests

\begin{tabular}{|c|c|c|c|c|c|c|c|c|c|}
\hline$\sqrt[5]{n}$ & $\sum_{\Sigma}^{\overline{0}}$ & $\begin{array}{l}\stackrel{0}{0} \\
\frac{0}{2} \\
\frac{\omega}{2}\end{array}$ & 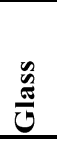 & $\stackrel{\oplus}{\Xi}$ & 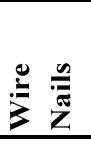 & 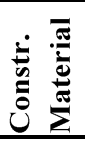 & $\stackrel{0}{.0}$ & 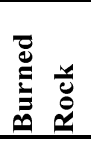 & $\begin{array}{l}\frac{n}{\pi} \\
\stackrel{5}{\theta} \\
\end{array}$ \\
\hline 38 & & & 3 & & & 1 & 2 & 1 & 7 \\
\hline 41 & & & & & & 1 & 1 & & 2 \\
\hline 42 & & & 1 & & & & 2 & & 3 \\
\hline 43 & & & & & & & 2 & & 2 \\
\hline 47 & & & 1 & & & 1 & 2 & 1 & 5 \\
\hline 53 & & & & & & 1 & & & 1 \\
\hline 55 & & & & & 1 & 1 & & & 2 \\
\hline 57 & & & 3 & & 1 & & 2 & 1 & 7 \\
\hline 58 & & & & 1 & & & 1 & & 1 \\
\hline 59 & & & & & & & 6 & & 6 \\
\hline 60 & 1 & 1 & & & & & & 1 & 3 \\
\hline 62 & & & 1 & & & 2 & 1 & & 4 \\
\hline 63 & & & & & & & 2 & & 2 \\
\hline $64 *$ & & & & & 1 & 2 & 4 & 2 & 9 \\
\hline 65 & & 1 & 1 & & & & & & 2 \\
\hline 67 & & & & & & & 1 & & 1 \\
\hline $69 *$ & & & & & & & 8 & 1 & 9 \\
\hline 71 & & & & & & & 1 & & 1 \\
\hline 72 & & & & & & & 1 & & 1 \\
\hline 73 & & & & & & & 2 & & 2 \\
\hline 74 & & & & 2 & & & 9 & 1 & 12 \\
\hline 75 & & & & & & & 3 & & 3 \\
\hline Totals & 1 & 2 & 10 & 3 & 3 & 9 & 50 & 8 & 86 \\
\hline
\end{tabular}

* 50-x-50-cm shovel tests

\section{Recent and Historic Artifacts}

The recent artifacts consist of construction materials such as brick fragments, ceramic tile and flooring fragments. Window glass and roofing nails were recovered primarily from Level $1(0-10 \mathrm{cmbs})$. Plastic and vinyl fragments, glass jar shards and a bottle fragment were also recovered from the shovel tests. All of the recent artifacts are from the mid to the late twentieth century, although a few of them may pre-date the 1950s but have a broad range of manufacture dates. One such example is part of the base of a green glass wine bottle. Unlike the rest of the glass recovered, the bottle fragment is heavily patinated. The form of this wine bottle fragment is one that has been common from the Colonial period up to the present and thus is not temporally diagnostic in a useful manner. The patina may indicate a greater age than the rest of the glass artifacts, but how much greater cannot be ascertained. The recent artifacts were concentrated in Level $1(0-10 \mathrm{cmbs})$ and may derive from the nearby residential neighborhood. As Table 2 shows, no historic materials were found below Level 3 (20-30 cmbs).

\section{Prehistoric Artifacts}

The prehistoric materials recovered consist of a total of 50 lithics (chipping debris) and eight angular burned rock specimens. The 50 lithics consist of 45 pieces of unmodified debitage, one retouched and one use-modified flake, two cores, and one heat spalled biface fragment. The unmodified debitage is composed of $37(82.2 \%)$ broken flakes, also called flake shatter (Andrefsky 1998) and only eight (17.8\%) complete flakes. An examination of flake types show $60.0 \%$ $(\mathrm{n}=27)$ resulted from core/platform preparation. Biface production accounts for $13.3 \%(n=6)$ of the flakes, $24.5 \%$ $(n=11)$ are of an unidentifiable type and one $(2.2 \%)$ is an overshot flake.

The core recovered from ST 57 has perhaps two flake removal scars that cannot be attributed to natural battering. The core from ST 73, Level 6, is bifacially worked with about 14 flakes struck off it in multiple directions. It is 312.9 grams in weight and $87.9 \mathrm{~mm}$ long by $78.5 \mathrm{~mm}$ wide and $51.5 \mathrm{~mm}$ thick. The cores found on the surface were of similar size. 
Table 2. Artifact Distribution by Level

\begin{tabular}{|c|c|c|c|c|c|c|c|c|c|c|}
\hline נָ & 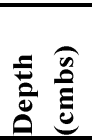 & $\sum^{\bar{\pi}}$ & 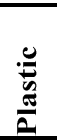 & $\begin{array}{l}n \\
\tilde{E} \\
\tilde{J} \\
\end{array}$ & 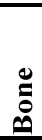 & 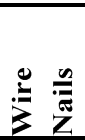 & 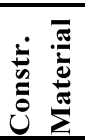 & 苞 & 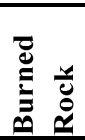 & $\begin{array}{l}\frac{n}{5} \\
\frac{\pi}{0} \\
\end{array}$ \\
\hline 1 & $0-10$ & & 2 & 6 & 1 & 3 & 5 & 13 & 3 & 33 \\
\hline 2 & $10-20$ & & & 3 & & & 3 & 19 & 2 & 26 \\
\hline 3 & $20-30$ & 1 & & 1 & 2 & & 1 & 5 & 2 & 12 \\
\hline 4 & $30-40$ & & & & & & & 9 & 1 & 10 \\
\hline 5 & $40-50$ & & & & & & & 2 & & 2 \\
\hline 6 & 50-60 & & & & & & & 2 & & 2 \\
\hline \multicolumn{2}{|c|}{ Totals } & 1 & 2 & 10 & 3 & 3 & 9 & 50 & 8 & 86 \\
\hline
\end{tabular}

The burned rock present in the shovel tests is mostly burned chert and gives no indication whether such fire cracking was caused by natural fires or by a specific human activity such as heat-treating chert for improved workability. It is highly doubtful that the chert would have been used in a hearth when limestone was so abundantly available. Therefore, it is probably that at least some of the few burned rock pieces are of recent origin.

The survey identified two light scatters of lithic artifacts along the edge of the Panther Springs Creek bluff. The first scatter was located adjacent to STs 38 and 71-75 from the current survey, and ST 31 from the 1997 survey (Figure 3). Shovel Test 74 had the highest lithic density on the site, yielding nine pieces of unmodified debitage. The second lithic scatter was located on a rise on the bluff edge of Panther Springs Creek. This rise is one to three meters higher than the rest of the park. The artifact scatter was found in STs $28-29$ of the 1997 survey and STs $41-43,57,59$ and 62-64 of the current survey (Figure 3). Within this artifact scatter, ST 59 had the highest lithic density, producing six pieces of unmodified debitage. Isolated shovel tests producing prehistoric artifacts were STs 47, 67 and 69 (Figure 3). ST 69 produced eight chipped lithic artifacts, including an edge-modified flake. Lithics were recovered from Level 1 through Level 6 (Table 2). The highest number came from Level 2 with $38 \%(\mathrm{n}=19)$ followed by Level 1 with $26 \%(n=13)$. The counts of prehistoric artifacts drop sharply below Level 4 (Table 2).

\section{Geoarchaeological Investigations} by Russell D. Greaves

Geoarchaeological investigations were performed as part of archaeological survey of the Walker Ranch Park property that includes site 41BX1271. Geoarchaeologists examined the landform and profiles in two shovel tests (STs 64 and 69) on January 20, 2003. Soil descriptions are presented in Tables 3 and 4, and the profiles are illustrated in Figures 4 and 5.
Panther Springs Creek and Salado Creek are ephemeral streams flowing eastward. Panther Springs Creek is a tributary of Salado Creek and they confluence approximately $1.65 \mathrm{~km}$ east of the eastern park boundary at West Avenue. The project area represents Quaternary terrace deposits resting on Cretaceous limestone (Black and McGraw 1985:41-42). These are primarily the Upper Cretaceous Austin Chalk formation (Fisher 1974). The soils are Lewisville silty clay (LvB), part of the Lewisville-Houston Black terrace association (Taylor et al. 1991:25, Sheet 28). These are generally moderately deep soils and are often underlain by alluvial gravels. Soil depths range from approximately $94-112 \mathrm{~cm}$ (37-44 in) below surface. Within Walker Ranch Park, these soils are moderately deep on the second oldest terrace ( $\mathrm{T}_{5}$ of Salado Creek) and thinner on the older $\mathrm{T}_{6}$ surface where the soils contain heavily weathered Cretaceous limestone at $15 \mathrm{~cm}$ below ground surface. The channel and recent terrace areas of both creeks are Trinity and Frio alluvial soils (Taylor et al. 1991:32).

The bed of Salado Creek is bedrock controlled. There are extensive limestone exposures forming the channel bed and outcropping along the northern bank of Salado Creek to the level of the $\mathrm{T}_{3}$ surface. This bedrock exhibits a stepped morphology. The southern bank of Panther Springs Creek is an incised exposure of limestone forming a steep cliff

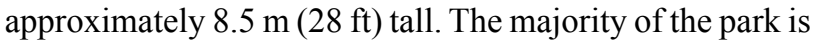
situated on the level $\mathrm{T}_{5}$ surface of Salado Creek. The profile of ST 69 records the soil on this terrace.

All the terraces are a conformable sequence from Salado Creek. The steep bedrock bank along the southern margin of Panther Springs Creek indicates that most of these terrace deposits do not derive from that drainage. The older terraces of that creek are situated north and northeast of the current channel. At the eastern end of the park there is some interfingering of $T_{1}$ and $T_{2}$ deposits from Panther Springs Creek with the $\mathrm{T}_{5}$ Salado Creek alluvium. At the western end of the park, the $T_{1}$ and $T_{2}$ deposits of Panther Springs Creek are situated below the elevation of the Salado Creek $\mathrm{T}_{5}$ unit, where these deposits have not been disturbed by 
construction for a housing development adjacent to the park property. There is a small remnant of a $T_{6}$ surface in the north-central portion of the park adjacent to Panther Springs Creek. It is inferred to be a deposit from Salado Creek because of the conformable terrace sequence and the bedrock southern bank of Panther Springs Creek. The profile of ST 64 was recorded on this oldest terrace soil. Minimally, some mechanical leveling disturbance of the upper portion of the soil profile has occurred during the initial park construction, affecting mostly the upper $\mathrm{T}_{5}$ soils.

\section{Geoarchaeological Findings}

\section{ST 64}

This shovel test was excavated on the highest and oldest terrace $\left(\mathrm{T}_{6}\right)$ of Salado Creek (Figure 3). This terrace deposit extends to the steeply incised bedrock margin of Panther Springs Creek. At the surface of that bank, there appears to be less than $1 \mathrm{~m}$ of soil above the relatively intact upper bedrock contact. ST 64 was excavated to a maximum depth of $60 \mathrm{~cm}$ below surface, but the profiled western wall sampled an area that extended only $55 \mathrm{~cm}$ and encountered very large weathered bedrock fragments. This unit is only apparent in the north-central portion of Walker Ranch Park. It is unknown if mechanical leveling resulted in removal of a portion of the expression of this terrace or it is a remnant restricted only to this area of the park. It is interesting that the highest archaeological recovery is from the $\mathrm{T}_{6}$ area and the eastern area of the park at the margin of the $\mathrm{T}_{6}$ surface. Because no examination of the soils in these eastern shovel tests was performed, it is not possible to determine if some of those deposits may be colluvium or mechanically redeposited sediments from the higher $\mathrm{T}_{6}$ surface. Three shovel tests in the southwestern portion of the $T_{5}$ surface also contained artifacts, although they did not form a continuous distribution as noted for $\mathrm{T}_{6}$ and the eastern portion of the $\mathrm{T}_{5}$ shovel test units.

Shovel Test 64 exhibited an A, Bt, B soil sequence with significant amounts of weathered limestone bedrock (Table 3 and Figure 4). All of the soils are poorly sorted, silty clay loams that are weakly developed. The Ap represents a zone of mechanical disturbance. It is too thin $(3-5 \mathrm{~cm})$ to represent a plow zone. A fine layer $(<3 \mathrm{~mm})$ of reddish sediment was present at the abrupt, erosional unconformity with the A horizon. This is the material that has been used as bedding material to underlay the paved pathways and is apparent on the path to the outdoor educational pavilion at the western end of Walker Ranch Park. A few pieces of historic debris and one lithic were recovered from Level $1(0-10 \mathrm{cmbs})$ in ST 64. Underneath the Ap is approximately $8-14 \mathrm{~cm}$ of A horizon that is thicker on the northern end than the southern end of the profile. This may reflect mechanical leveling or the effects of natural erosion of this former epipedons (uppermost soil layers). The A horizon silty clay loam exhibits moderate effervescence and contains many small $(<1 \mathrm{~cm})$ limestone clasts. There are few, thin, discontinuous clay films apparent on ped faces only. This may indicate that mechanical leveling has removed an older A horizon and the current $\mathrm{A}$ horizon underneath the recent fill material still retains clay films because it was formed as a Bt soil. The Bt horizon underneath the A horizon is distinguished by strong effervescence, many clasts $<4 \mathrm{~cm}$, and clay bridges between grains in addition to the presence of few, thin, discontinuous clay films on ped faces. This soil is $11-14$ $\mathrm{cm}$ thick and has a gradual and irregular lower boundary. A single lithic and one piece of construction material was collected from Level $2(10-20 \mathrm{cmbs})$ that sampled the lower half of the A horizon and the upper portion of the underlying $\mathrm{Bt}$. The B1 horizon has much less clay apparent and contains abundant limestone clasts that are $<12 \mathrm{~cm}$ in maximum dimension. The morphology of these clasts indicate that they are not alluvial gravels but appear to represent in situ weathered bedrock. Two flakes were recovered from excavation Level 4 that corresponds very closely to the boundaries of the B1 horizon. Underneath the B1 horizon is a unit containing abundant large clasts $(<25 \mathrm{~cm})$. There is much less soil between these pieces of weathered bedrock, although the unit is not imbricated (overlapping) but may be clast supported. The soil in this unit is identical to the above unit but exhibits single grain-fine structure compared with the fine-medium subangular block structure of the overlying B1 horizon. The presence of a few thin, discontinuous clay bridges suggests some in situ pedogenesis (soil development), but it may also represent material infilling around weathered bedrock and share characteristics of a $\mathrm{Cr}$ horizon. No artifacts were recovered from this lowermost unit.

\section{ST 69}

This shovel test was situated in the southwestern portion of the level $\mathrm{T}_{5}$ surface (Figure 3). This is one of three shovel tests in this portion of Walker Ranch Park that contained prehistoric artifacts (ST 47 and ST 67). ST 69 was excavated to a maximum depth of $50 \mathrm{cmbs}$. The western wall of this unit was profiled and described.

Descriptions of the soils in ST 69 are provided in Table 4 and the profile drawing is shown in Figure 5. ST 69 demonstrated an A, B, Bt sequence with a minimum of clasts identified in any of the soils. Although there is limestone bedrock outcropping along Salado Creek approximately 80 $\mathrm{m}$ southwest of this unit, these surface expressions indicate that bedrock is much more deeply buried than on the $T_{6}$ deposit. The A horizon is $9-12 \mathrm{~cm}$ thick and shows no 

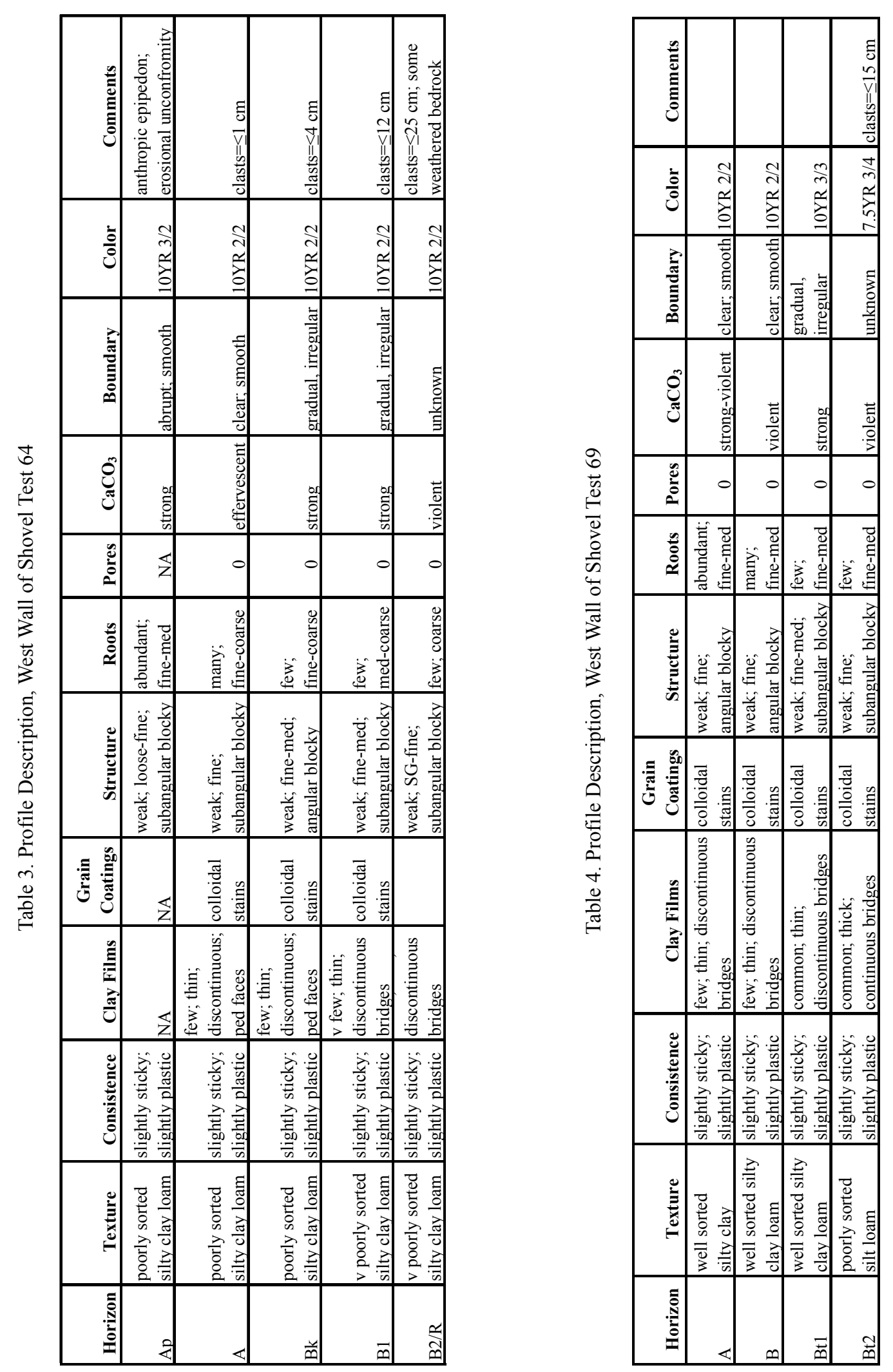
apparent disturbance. This is a well-sorted silty clay that is weakly developed. There was no apparent zone of recent disturbance identified in the upper portion of this shovel test . A very few, thin, discontinuous clay bridges are present in the A horizon that may suggest this is a remnant B horizon. Three pieces of debitage and one fragment of FCR were recovered in excavation Level 1 that correlated with this natural soil unit. The $\mathrm{B}$ horizon extends $9-12 \mathrm{~cm}$ below the A and is distinguished by having a very slightly greater expression of thin, discontinuous, clay bridges. As noted above, if mechanical leveling has removed an epipedon, this may represent a B2 unit and the current A would be classified as $\mathrm{B} 1$ because of the evidence of minor clay bridge formation. The B horizon also correlates well with the arbitrary Level 2 that contained two lithics. The underlying Bt1 exhibits common, thin, discontinuous clay bridges and its weak structure is associated with larger peds (finemedium). This unit has a gradual and irregular lower boundary and ranges between 7 and $14 \mathrm{~cm}$ thick. Most of Level 3 is restricted to this horizon and produced a single lithic. The Bt 2 is the lowest horizon identified and is at least $12-17 \mathrm{~cm}$ thick. This soil is slightly redder (7.5YR 3/4) than all of the overlying solum and contains a few clasts that are $<15 \mathrm{~cm}$ in size. The clay bridges are common, thick, and continuous, but do not form films. Two flakes were recovered from Level 4 which includes the lower portion of $\mathrm{Bt} 1$ and the upper half of $\mathrm{Bt} 2$.

\section{Geoarchaeology Discussion}

Soil profiling of the two shovel tests confirm the surface geomorphology identifying the relative ages of the terraces within the main recreational areas of Walker Ranch Park. All of the improved portions of the park appear to be on abandoned terraces of Salado Creek. Soils examined in ST 69 exhibit slightly less developed structure (only Bt1 has peds ranging from fine-medium) and have no greater clay accumulation than common, thick and continuous bridges seen in the Bt2 soil. Both the Bt1 and B horizons in ST 64 have fine-medium sized peds that are weakly developed and there are clay films on ped faces in both the A and Bt horizons. The $\mathrm{T}_{6}$ sediments contain clasts of weathered bedrock that fine upwards (the rock sizes gets smaller) and are mixed with the soil matrix. In addition to their position on what is probably higher subsurface bedrock, this suggests a greater time depth involving in situ weathering of the uppermost bedrock and pedogenesis that includes those weathered clasts into the soil fabric. The clear sorting of clasts indicates a lack of subsurface disturbance of these terrace soils. Both of the shovel tests contained evidence that some of the A horizons have been mechanically removed, although only ST 64 shows an erosion contact and a thin mantle of anthropic fill. The current A horizons in both profiles have clay films (ST 64) or clay bridges (ST 69). There is no apparent plowing disturbance.

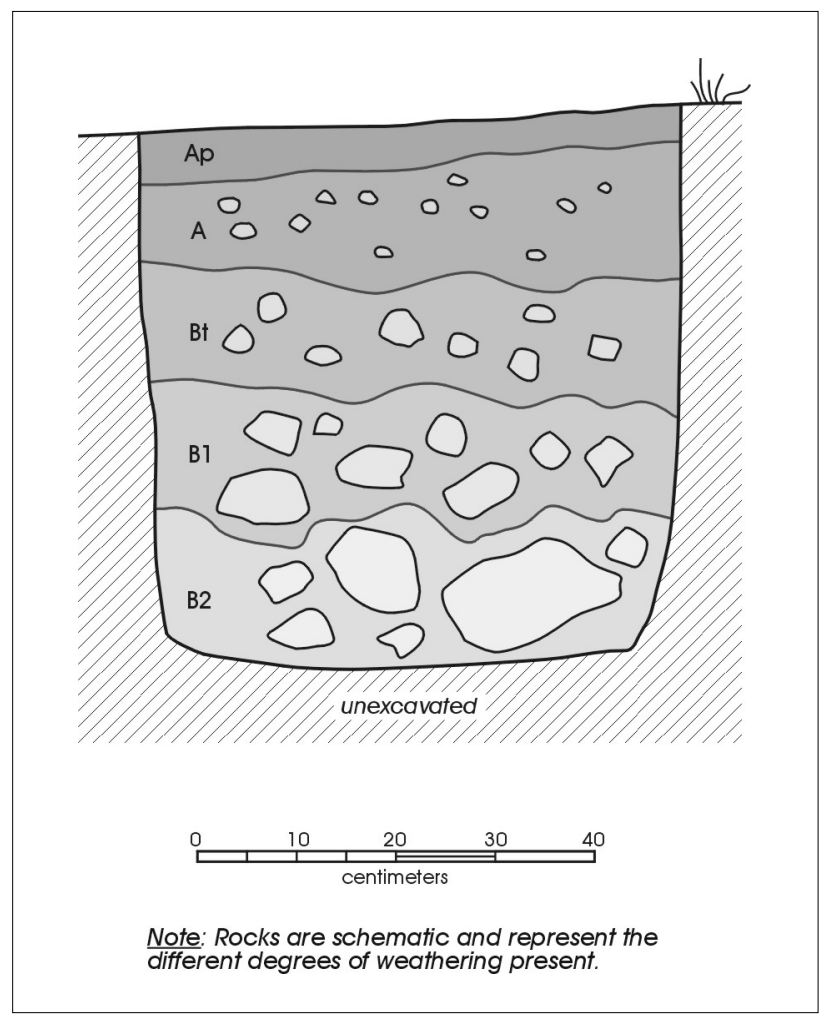

Figure 4. Profile of west wall of Shovel Test 64.

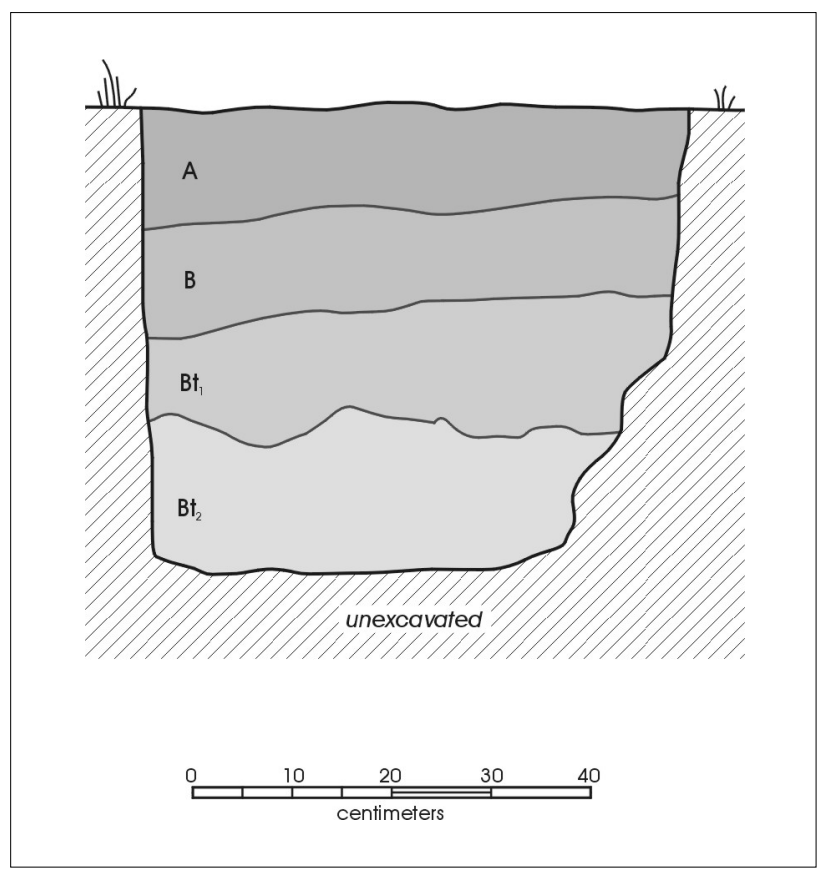

Figure 5. Profile of west wall of Shovel Test 69. 
This seems unusual for this location as part of a former ranch and the recognition of the Lewisville soils as among the most productive agricultural soils in Bexar County (Taylor et al. 1991:25). However, the narrow portion of land between the two drainages forming the park property may have provided too restricted a potential field for frequent use. Although some historic materials were recovered, there is no evidence of significant disturbance of the prehistoric deposits.

The depth of these soils and their apparent integrity indicate a very strong probability that at least some of the archaeological deposits of 41BX1271 retain significant integrity. The $\mathrm{T}_{6}$ area in the north-central portion of Walker Ranch Park, adjacent to the southern bank of Panther Springs Creek, represents the oldest surface within the improved portion of the park. This terrace contained the greatest contiguous evidence of archaeological occupation debris. There was more historic debris in this area than the other portions of the park, mostly confined to the uppermost portion of the soil profile. There is a contiguous artifact distribution in the shovel tests in the eastern portion of the park on $\mathrm{T}_{5}$ (ST 38 and STs 71-75), some with relatively deeply buried lithics. The three units in the southwestern portion of $\mathrm{T}_{5}$ with isolated prehistoric materials also produced flakes from deeper contexts. Neither of these smaller distributions of cultural materials suggests colluvially redeposited artifacts from the $\mathrm{T}_{6}$ occupation. Lithics were recovered in the eastern area to depths of $60 \mathrm{cmbs}$ (in ST 74). The soil profile of ST 69 and the presence of a relatively high density of lithics in the deeper deposits (at least $40 \mathrm{cmbs}$ ) as compared to other shovel tests indicate that these artifacts may be in primary context. None of the profiles indicated that recent activities have compromised the subsurface integrity of the prehistoric archaeological record. In the absence of more detailed opportunities for geoarchaeological examination or archaeological excavation, it cannot be determined if multiple occupations of the two highest terraces of Salado Creek are indicated or if contemporaneous use of those two surfaces represents a more restricted temporal prehistoric presence at this location.

\section{Conclusions and Recommendations}

The recent and few historic artifacts at the site are thinly scattered across the park. The bulk of these materials date from the mid to the late twentieth century. The items recovered are likely from the nearby residential neighborhood. The prehistoric artifacts found both on surface and in the shovel tests occur in low densities and no features were identified during this project. No temporally diagnostic artifacts were found. The geoarchaeological investigations showed that, in places, buried deposits are intact and have integrity along the Panther Springs Creek bank. The prehistoric artifacts, namely the debitage and cores, indicate a wide range of activities at the site directed toward raw material procurement and chipped stone tool production. The relatively low artifact density indicates that occupations at the site were intermittent and short-term.

While some of the archaeological deposits present at site 41BX1271 in Walker Ranch Park are intact, they occur in low density and contain no diagnostic artifacts or features that could have higher research value. The area investigated and the artifacts recovered have low research potential and minimal interpretive value. It is recommended that the park improvements project, including the installation of the lighting poles and water fountain, proceed as planned. It is recommended then, that any future construction projects resulting in subsurface disturbances should be preceded by archaeological testing in much the same manner as was conducted for this project. This especially holds true for any activity in the vicinity of the two, low-density lithic concentrations along Panther Springs Creek (ST 38 and STs 71-75, and STs 41-43 and 57-64). We commend the San Antonio Parks and Recreation Department for their continued care for the cultural resources found within properties managed by them and their cooperation during this project. 


\section{References Cited}

Andrefsky, W. Jr.

1998 Lithics: Macroscopic Approaches to Analysis. Cambridge Manuals in Archaeology. Cambridge University Press, London.

Black, S. L., and A. J. McGraw

1985 The Panther Springs Creek Site: Cultural Change and Continuity within the Upper Salado Creek Watershed, South-Central Texas. Archaeological Survey Report, No. 100. Center for Archaeological Research, The University of Texas at San Antonio.

Black, S. L., K. Jolly, C. D. Frederick, J. R. Lucas, J. W. Karbula, P. R. Takac, and D. R. Potter

1998 Archeology along Wurzbach Parkway, Module 3. Investigations and Experimentation at the Higgins Site (41BX184), Vol. 1. Studies in Archeology 27. Texas Archeological Research Laboratory, The University of Texas at Austin.

Bomar, G. W.

1995 Texas Weather. University of Texas Press, Austin.

Brown, D. O., P. Lukowski, T. R. Hester, and J. D. Eaton

1977 Archaeological Assessment of Two Sites in the Vicinity of Floodwater Retarding Structure No. 11, Salado Creek Watershed, Bexar County, Texas. Archaeological Survey Report, No. 35. Center for Archaeological Research, The University of Texas at San Antonio.

Burkett, R. W.

1989 Archaeological Testing (Phase II) of Prehistoric Site 41BX785 for the West Salado Creek Outfall Project, Bexar County, Texas. Archaeological Survey Report, No. 182. Center for Archaeological Research, The University of Texas at San Antonio.

Burkett, R. W., and J. A. Huebner

1989 An Archaeological Assessment (Phase I) of the West Salado Creek Outfall Project, Southeastern Bexar County, Texas. Archaeological Survey Report, No. 181. Center for Archaeological Research, The University of Texas at San Antonio.

Campbell, T. N.

1975 The Payaya Indians of Southern Texas. Southern Texas Archaeological Association Special Publication 1. San Antonio.

Chapa, J. Bautista

1997 Historia del Nuevo Reino de León. In Texas and Northeastern Mexico, 1630-1690, edited by J. Bautista Chapa and W. C. Foster, p. 91. Translated by N. F. Brierley. University of Texas Press, Austin.

Collins, M. B.

1995 Forty Years of Archeology in Central Texas. Bulletin of the Texas Archeological Society 66:361-400.

1999 Clovis Blade Technology. The University of Texas Press, Austin.

Collins, M. B., J. Guy, and S. W. Dial

1998 The Archaic Period: 8800-1300 B.P. In Wilson Leonard: An 11,000-year Archeological Record of HunterGatherers in Central Texas: Volume 1: Introduction, Background, and Synthesis, edited by M. B. Collins, pp. 211-270. Studies in Archeology 31, Texas Archeological Research Laboratory, The University of Texas at Austin. 
Fisher, W. L.

1974 Geologic Atlas of Texas: San Antonio Sheet. Robert Hamilton Cuyler Memorial Edition. Bureau of Economic Geology, The University of Texas at Austin.

Fox, A. A.

1979 Archaeological and Historical Investigations at 41BX180, Walker Ranch, San Antonio Texas: Phase 1. Archaeological Survey Report, No. 83. Center for Archaeological Research, The University of Texas at San Antonio.

Henderson, J.

2001 Excavations at the Rainey Site (41BN33), A Late Prehistoric Sinkhole Site in Bandera County, Texas. Archeological Studies Program Report 5. Texas Department of Transportation, Environmental Affairs Division, Austin.

Hester, T. R.

1990 Notes on South Texas Archaeology: 1991-2: The Plainview Points from the St. Mary's Hall Site, South-Central Texas. La Tierra 18(2):1-4.

Hester, T. R., F. A. Bass, A. A. Fox, T. C. Kelly, M. F. Chadderdon, and E. S. Harris

1974 Archaeological Survey of Areas Proposed for Modification in the Salado Creek Watershed, Bexar County, Texas. Archaeological Survey Report, No. 3. Center for Archaeological Research, The University of Texas at San Antonio.

Johnson, L.

1991 Early Archaic Life at the Sleeper Archaeological Site, 41BC65 of the Texas Hill Country, Blanco, County, Texas. Publication in Archaeology 39. Texas Department of Highways and Public Transportation, Highway Design Division, Austin.

1995 Past Cultures and Climates at Jonas Terrace, 41ME29, Medina County, Texas. Office of the State Archeologist Report 40. Texas Department of Transportation and Texas Historical Commission. Austin.

Johnson, L., and G. T. Goode

1994 A New Try at Dating and Characterizing Holocene Climates, as well as Archeological Periods, on the Eastern Edwards Plateau. Bulletin of the Texas Archeological Society 65:1-51.

Katz, P. R.

1987 Archaeological Mitigation at 41BX300, Salado Creek Watershed, South-Central Texas. Archaeological Survey Report, No. 130. Center for Archaeological Research, The University of Texas at San Antonio.

Kibler, K. W., and A. M. Scott

2000 Archaic Hunters and Gatherers of the Balcones Canyonlands: Data Recovery at the Cibolo Crossing Site (41BX377), Camp Bullis Military Reservation, Bexar County, Texas. Reports of Investigations, Number 126. Prewitt \& Associates, Inc., Austin.

Krieger, A. D.

2002 We Naked and Barefoot: The Journey of Cabeza de Vaca Across North America. The University of Texas Press, Austin.

Lukowski, P.

1988 Archaeological Investigations at 41BX1, Bexar County, Texas. Archaeological Survey Report, No. 135. Center for Archaeological Research, The University of Texas at San Antonio. 
LBJ School of Public Affairs

1978 Preserving Texas'Natural Heritage. LBJ School of Public Affairs, Report 31. Austin.

Mahoney, R. B., H. J. Shafer, S. A. Tomka, L. C. Nordt, and R. P. Mauldin

2003 Royal Coachman (41CM111): An Early Middle Archaic Site along Cordova Creek in Comal County, Texas. Archaeological Survey, Report No. 332, Center for Archaeological Research, The University of Texas at San Antonio; Archeological Studies Program, Report No. 49, Environmental Affairs Division, Texas Department of Transportation, Austin.

McGraw, A. J., and F. Valdez

1978 Investigation of Prehistoric Rockshelter and Terrace Sites along Portions of the Salado Creek Drainage, Northern Bexar County, Texas. Archaeological Survey Report, No. 55. Center for Archaeological Research, The University of Texas at San Antonio.

Meissner, B. A.

2000 Monitoring of Excavations for Construction of an Outdoor Classroom Facility at Walker Ranch Park (41BX1271), San Antonio, Texas. Letter Report, No. 127. Center for Archaeological Research, The University of Texas at San Antonio.

Miller, K. H.

2001 Archaeological Survey of the West Salado Creek Lift Station Project, San Antonio, Texas. Archaeological Survey Report, No. 310. Center for Archaeological Research, The University of Texas at San Antonio.

Nickels, D. L., C. B. Bousman, J. D. Leach, and D. A. Cargill

2001 Test Excavations at the Culebra Creek Site, 41BX126, Bexar County, Texas. Archaeological Survey Report, No. 265, Center for Archaeological Research, The University of Texas at San Antonio; Archeology Studies Program, Report 3. Environmental Affairs Division, Texas Department of Transportation, Austin.

Potter, D. R.

1980 An Archaeological Assessment of 41 BX197 and Vicinity, Walker Ranch National Register Historic District, San Antonio, Texas. Archaeological Survey Report, No. 91. Center for Archaeological Research, The University of Texas at San Antonio.

Potter, D. R, and S. L. Black

1995 Archeology Along the Wurzbach Parkway, Module 2, Initial Testing and Evaluation of Five Prehistoric Sites in the Upper Salado Watershed, Bexar County, Texas. Studies in Archeology 17. Texas Archeological Research Laboratory, The University of Texas at Austin.

Potter, D. R, S. L. Black, and K. Jolly

1995 Archaeology Along the Wurzbach Parkway, Module 1, Introduction, Conceptual Framework and Contexts of Archaeological Investigations in Bexar County, South-Central Texas. Studies in Archeology 17. Texas Archeological Research Laboratory, The University of Texas at Austin.

Riskind, D. H., and D. D. Diamond

1988 An Introduction to Environment and Vegetation. In Edwards Plateau Vegetation: Plant Ecological Studies in Central Texas, edited by B. B. Amos and F. R. Gehlbach, pp. 1-16. Baylor University Press, Waco, Texas.

Soil Survey Staff

1993 Soil Survey Manual. U.S. Department of Agriculture Handbook No. 18. U.S. Department of Agriculture. U.S. Government Printing Office, Washington, D.C. 
Stothert, K. E.

1989 The Archaeology and Early History of the Head of the San Antonio River. Southern Texas Archaeological Association Special Publication Number 5, and Incarnate Word College Archaeology Series No. 3. San Antonio.

Taylor, F. B., R. B. Hailey, and D. L. Richmond

1991 Soil Survey of Bexar County, Texas. United States Department of Agriculture, Soil Conservation Service. Washington, D.C.

Thoms, A. V., D. D. Kuehn, B. W. Olive, J. E. Dockall, P. A. Clabaugh, and R. D. Mandel

1996 Early and Middle Holocene Occupations at the Richard Beene Site: The 1995 Southern Texas Archaeological Association Field School Project. La Tierra 23(4):8-36.

Tomka, S. A.

1998 An Archaeological Survey of Walker Ranch Park, Bexar County, Texas. Archaeological Survey Report, No. 282. Center for Archaeological Research, The University of Texas at San Antonio.

Turner, E. S., and T. R. Hester

1999 A Field Guide to Stone Artifacts of Texas. Gulf Publishing Co., Houston. 